\title{
Identification of sources and infiltration regimes of nitrate in the semi-arid Kalahari: Regional differences and implications for groundwater management
}

\author{
S Stadler ${ }^{1 *}$, AS Talma $^{2}$, G Tredoux ${ }^{3}$ and J Wrabel ${ }^{4}$ \\ ${ }^{1}$ Federal Institute for Geosciences and Natural Resources (BGR), Stilleweg 2, D-30655 Hannover, Germany \\ ${ }^{2}$ CSIR (Natural Resources and the Environment), PO Box 395, Pretoria 0001, South Africa \\ ${ }^{3}$ CSIR (Natural Resources and the Environment), PO Box 320, Stellenbosch 7599, South Africa \\ ${ }^{4}$ Ministry of Water Affairs and Forestry, Windhoek, Namibia
}

\begin{abstract}
The Kalahari region of southern Africa offers much potential for nitrogen input into its groundwater. High nitrate concentrations in Kalahari groundwater are therefore quite common and are caused by both anthropogenic and natural sources. Forecasting groundwater nitrate concentrations remains challenging. Source identification of nitrate contamination in groundwater is an important first step for groundwater management and quality prediction, and is aided by isotope analysis of nitrate in the water. Comparative data from 3 groundwater study sites in the Kalahari of Botswana and Namibia with widely different characteristics are presented. Two of the sites (Ghanzi and Gobabis) have shallow water tables in fractured quartzite. These aquifers were affected by pollution from cattle wastes (manure) and septic tank outflows resulting in groundwater nitrate levels exceeding $1000 \mathrm{mg} \mathrm{NO} / \ell$ and in $\delta^{15} \mathrm{~N}$ values of between +7 and $+20 \%$ AIR. Short-term increases of groundwater nitrate concentrations were triggered by exceptional rainfall events occurring every 10-20 years. At the third site (Serowe in Botswana) there is similar land use and land cover, yet the aquifers are deeper, groundwater dates to Late-Pleistocene age and borehole levels do not show a response to present-day high-rainfall episodes. Nitrate levels up to $219 \mathrm{mg} / \ell$ are found, but lower ${ }^{15} \mathrm{~N}$ content $\left(\delta^{15} \mathrm{~N}\right.$ of +3 to $+8 \%$ ) indicates a natural origin of the nitrate. In this area pollution nitrate is sufficiently delayed in the vadose zone, reaching the saturated zone much later. The data from all 3 sites suggest that nitrogen management options can only be evaluated once an understanding of sources, processes and flow patterns has been established.
\end{abstract}

Keywords: nitrate, groundwater contamination, stable isotopes, ${ }^{15} \mathrm{~N}$, recharge, flow, aquifer

\section{Introduction}

Nitrate is a common groundwater contaminant that has severe health implications for infants and animals (WHO, 1998; Addiscott et al., 1991). Exceedances of the WHO guideline value of $50 \mathrm{mg} / \ell$ (as $\mathrm{NO}_{3}$ ) for drinking water for humans (WHO, 1998) are observed in many countries. Nitrate is reduced to nitrite in the digestive system of a ruminant and then forms methaemoglobin which reduces the oxygen transport capacity of the blood. Without adaptation and the generation of enzymes for decomposing methaemoglobin, the rapid intake of excessive nitrate levels in the water will kill the animals due to asphyxiation (Carlson and Breeze, 1984). Ruminants can tolerate quite high levels of nitrate but need a period to adapt to increasing levels, which has led some countries to introduce different nitrate guideline values for different types of livestock (e.g. $100-400 \mathrm{mg} \mathrm{NO} / \ell$ in South Africa) (DWAF 1996).

In temperate climate regions, increased nitrate concentrations are almost exclusively of anthropogenic origin, mainly related to agricultural activities and sewage problems (e.g. Tredoux and Talma, 2006; Razoskowa-Jaworek and Sadurski,

\footnotetext{
* To whom all correspondence should be addressed.

III +49-511-643 3545/3665; fax: +49-511-643 3545/3665; e-mail: susanne.stadler@bgr.de

Received 7 June 2011; accepted in revised form 2 April 2012
}

2004; Canter, 1997). Similarly, studies in (semi-)arid locations have shown increased nitrate concentrations attributed to unsewered sanitation and sewage leaching (Anayah and Almasri, 2009; Jacks et al., 1999; Williams et al., 1998; Jacks and Sharma, 1983), animal waste (e.g. Shomar et al., 2008; Lafthoui et al., 2003; Tredoux et al., 2001; Foster, 1985; Heaton, 1984), the influence of agricultural practices (e.g. Kaown et al., 2009; Saadi and Maslouhi, 2003; Pacheco et al., 2001; Hadas et al., 1999; Edmunds and Gaye, 1997; Heaton, 1985), influence from mines (Rosenthal et al., 1988) or land-use changes (e.g. Favreau et al., 2003; Girard and Hillaire-Marcel, 1997). In (semi-)arid regions, however, natural processes have additionally been identified as sources of elevated nitrate levels in groundwater, due to the dominance of various forms of biological nitrogen fixing over the complementary nitrate consumption by plants (Stadler et al., 2008; Lowe and Wallace, 2001; Edmunds and Gaye, 1997; Verhagen, 1995; Barnes et al., 1992; Marrett et al., 1990; Rosenthal et al., 1987; Heaton et al., 1983; Lawrence, 1983).

Isotopic methods aid the understanding of the processes taking place in the groundwater system (saturated and unsaturated zones), their timing and the sources of water and pollutants (Geyh, 2000). Time scales are especially important in arid areas where recharge is low and sporadic, and may have been quite different in the past (De Vries, 1984). The isotopic composition of nitrate $\left({ }^{15} \mathrm{~N} /{ }^{14} \mathrm{~N}\right.$ and $\left.{ }^{18} \mathrm{O} /{ }^{16} \mathrm{O}\right)$ is a useful indicator of the sources of nitrogen to groundwater (see general review by Kendall (1998), and local applications in Talma and Tredoux 


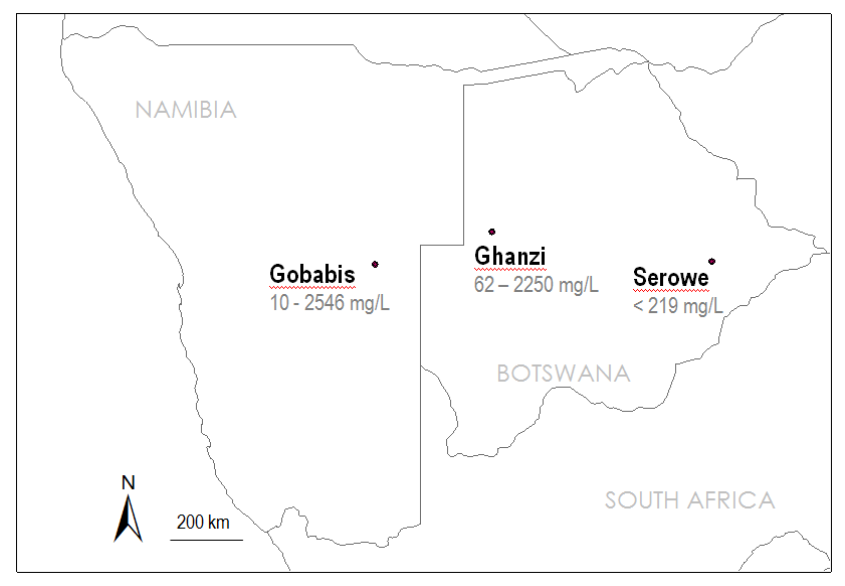

Figure 1

Location map of the study areas. Numbers indicate the range of observed nitrate concentrations in the groundwater $\left(\right.$ as $\left.\mathrm{NO}_{3}\right)$.

(2005)). In general, a grouping of ${ }^{15} \mathrm{~N} /{ }^{14} \mathrm{~N}$ indicates whether the nitrogen is derived from natural sources (nitrification on plants, mineralisation of plant remains) or from pollution sources (seepage from cattle manure or sewage). In the savanna areas of the Kalahari, nitrogen can also be contributed as a non-point source from the wastes of roaming livestock. Depending on the local circumstances, such nitrogen can circulate through the vegetation prior to recharge and lose its original ${ }^{15} \mathrm{~N} /{ }^{14} \mathrm{~N}$ signature in favour of that of the natural vegetation (Böhlke, 2002). ${ }^{18} \mathrm{O} /{ }^{16} \mathrm{O}$ indicates the oxygen source for nitrification and identifies those situations where nitrate is derived from direct atmospheric input. During denitrification both ratios, ${ }^{15} \mathrm{~N} /{ }^{14} \mathrm{~N}$ and ${ }^{18} \mathrm{O} /{ }^{16} \mathrm{O}$, increase in the ratio $2: 1$; a correlation between these 2 ratios indicates that denitrification may occur (Kendall, 1998).

The purpose of this paper is to show that source attribution of nitrate coupled to an understanding of hydraulic regimes is necessary in order to apply proper groundwater management strategies in these semi-arid settings. Using 3 examples from the Kalahari Thirstland, we review scenarios of recharge, nitrate input and hydraulic regimes, and indicate the consequences on the resultant groundwater properties. The 3 examples are regional studies from Ghanzi (Botswana), Serowe (Botswana) and Gobabis (Namibia), selected with the aim of contrasting different nitrate input and replenishment conditions. The aim of the paper is to point out that situations that appear comparable in terms of nitrate input and environmental conditions may require completely different management approaches because of aquifer structure and underground processes.

\section{The Kalahari setting}

The Kalahari is a large $\left(900000 \mathrm{~km}^{2}\right)$ sandy area covering most of Botswana and parts of Namibia and South Africa (Thomas and Shaw, 1991). The area is arid to semi-arid with virtually no surface water except for very limited periods. Precipitation ranges between 200 and $500 \mathrm{~mm} / \mathrm{a}$ and is restricted to one annual rainy season from September to April. Potential evaporation ranges from 2000 to more than $3000 \mathrm{~mm} / \mathrm{a}$. During short spells of high-intensity rainfall, the rainfall can exceed the evapotranspiration for a long enough period to induce recharge, usually through transport via preferential flow paths (e.g. De Vries and Simmers, 2002; Lubczynski, 2000; Selaolo, 1998; SGAB, 1988). The extent of groundwater recharge is primarily determined by the thickness of the sand cover and is therefore most visible at or near rock outcrops, as indicated by elevated levels of ${ }^{14} \mathrm{C}$ and tritium (Verhagen et al., 1974). Despite the absence of surface water and springs, the Kalahari is not generally described as a desert, since it does, in fact, support extensive plant, animal and human life. The local term developed is the Kalahari 'Thirstland' in recognition of the fact that sustainable life is possible, though difficult (Thomas and Shaw, 1991).

The soils of the Kalahari are described as mainly being arenosols. The depth to the underlying aquifer can be between 0 and $300 \mathrm{~m}$ (Thomas and Shaw, 1991). The vegetation is mainly savanna: Acacia trees with annual and perennial grass. Many of the trees and grasses host nitrogen-fixing organisms that, together with the low recharge, produce significant levels of nitrate in the groundwater (Tredoux et al., 2001). Many trees are deep-rooted (up to tens of metres deep) and, utilising deep soil moisture, create micro-habitats on the surface. The animals in the area have to live under harsh conditions and game tends to migrate - as far as it is still possible. Human life has existed mainly on the fringes of the Kalahari for the last 2000 years (Thomas and Shaw, 1991). At present, the population is entirely dependent on groundwater and water supply is an important government function. The lack of water and the low soil fertility prevents any agriculture. Animal husbandry (cattle and to a lesser extent goats) is the main economic activity and is maintained by many boreholes, as well as some open wells that are located in pans.

Elevated nitrate concentrations in groundwater are found in many parts of the Kalahari (Tredoux and Talma, 2006; Tredoux et al., 2001), since the Kalahari region offers much potential for nitrogen input, both of anthropogenic and of natural origin (Stadler et al., 2008; Heaton, 1984; Heaton et al., 1983). Due to the absence of agriculture that might use fertiliser, no industry and only sparse population, the dominant anthropogenic nitrate input in the Kalahari may be expected to be from cattle faecal material and local occurrences of human wastes that contaminate aquifers (Zwikula, 2005; Jacks et al., 1999). This may locally manifest itself as a non-point source from diffusely-deposited manure, which may get cycled between soil and plants before leaching to the groundwater (Schwiede, 2007; Böhlke, 2002). Alternatively, animal waste may be rapidly mineralised and transported to the water table at rates too rapid for nitrogen to recycle through vegetation. Factors contributing to the natural presence of nitrate in groundwater of the Kalahari are:

- the presence of plants (Acacia spp., other legumes and grasses) (Ringrose et al., 1998) or fauna (e.g. termites) symbiotic with nitrogen fixers (Barnes et al., 1992);

- very low recharge rates, usually less than $5 \mathrm{~mm} / \mathrm{a}$ (e.g. summarised in Selaolo, 1998); and

- episodic rainfall years causing sporadic aquifer recharge and leaching of nitrate from the unsaturated zone.

Wild animals are not very plentiful in the area and are not assumed to play, or have played, an important role in contributing nitrate to the aquifers. Recharge processes, through the often vast thickness of the unsaturated zone, may play a more significant role regarding the transport of dissolved species in semi-arid to arid regions than would be the case in more temperate regions. Recharge amounts and distribution in semiarid regions are strongly controlled by site-specific factors, e.g., topography, surface lithology, unsaturated zone properties and thickness, as well as climatic factors. These factors will 
also increase nitrate levels in polluted situations and render the prediction of the nitrate concentration pattern challenging. Occasional occurrences of rapidly rising nitrate levels in groundwater due to excessive rainfall were reported for the western Kalahari in 1974 (Tredoux and Talma, 2006; Wrabel, 2005).

\section{Nature of the constituent projects}

The Ghanzi investigation was undertaken in response to massive cattle deaths in the area due to nitrate poisoning of groundwater, and involved field studies and monitoring between 2000 and 2006 (Talma et al., 2009; Tredoux and Talma, 2006; Tredoux et al., 2005). The Gobabis study consisted of 20 -year monitoring of boreholes by the Department of Water Affairs of Namibia, followed by a one-time survey to investigate high, and variable, nitrate occurrences in groundwater of the western Kalahari, following on the Ghanzi example (Wrabel, 2005; Heaton, 1984). The Serowe study reported here represents a study on the origin and fate of nitrate, the fieldwork for which was conducted between 2002 and 2004 and resulted in $2 \mathrm{Ph} . \mathrm{D}$ theses (Schwiede, 2007; Stadler, 2005). Though these 3 projects were of a different nature and intensity, the investigations together provide a picture of the range of groundwater nitrate occurrences in the Kalahari.

The 3 areas (Fig. 1) were studied in the context of a regional research co-operation between the Council for Scientific and Industrial Research of South Africa (CSIR), the German Geological Survey (BGR), the Ministry of Water Affairs and Forestry of Namibia (MAWF) and the Department of Geological Survey of Botswana (DGS). This co-operation agreement enabled the participant organisations to share resources and exchange information about groundwater projects dealing with nitrate.

The field methods are described in the original papers published on each project (Stadler et al. 2010a; Stadler et al., 2008; Tredoux and Talma, 2006; Stadler, 2005; Tredoux et al., 2005; Wrabel, 2005). Water analyses were done for each project using the standard methods of each laboratory (identified in the acknowledgements and in the above-listed papers). Analysis of the isotopic composition of dissolved nitrate $(15 \mathrm{~N}$ and $18 \mathrm{O}$ in NO3) at UFZ followed the method of Silva et al., (2000). All nitrate concentrations in this paper are reported as $\mathrm{mg} \mathrm{NO} / \ell$. $\delta 15 \mathrm{~N}$ isotope ratios are reported in parts per thousand difference (\%) from the AIR (atmospheric nitrogen) standard and $\delta 18 \mathrm{O}$ isotope ratios as parts per thousand difference (\%) from SMOW (Standard Mean Ocean Water). Tritium is reported in Tritium Units (TU) which corresponds to $13 \mathrm{H}$ atom per 1018 $1 \mathrm{H}$ atoms.

\section{Results and discussion of the different studies}

\section{Ghanzi, Western Botswana}

The Ghanzi Ridge is a prominent topographic feature in northwestern Botswana, extending over several hundred kilometres into eastern Namibia, elevated at Ghanzi town in north-west Botswana (Fig. 1) about $300 \mathrm{~m}$ above the surrounding Kalahari sands (Modie, 1996). Groundwater is found in secondary fractures in the Neoproterozoic cemented sandstone, quartzites and schists (Table 1). Local sand cover ranges from 0 to $20 \mathrm{~m}$. Water strikes may vary from 22 to $200 \mathrm{~m}$ below surface (Morosini, 1996). After periods of high rainfall, groundwater levels can, for a few years, be as shallow as $3 \mathrm{~m}$ below the surface (Tredoux et al., 2005). Litherland (1982) states that the Ghanzi Group aquifer is recharged annually by surface runoff and seepage. Groundwater in the area is renowned for high nitrate: up to $652 \mathrm{mg} / \ell$ has been recorded, with a trend that deeper water strikes have lower nitrate levels (Morosini, 1996). Radiocarbon concentrations of greater than $80 \mathrm{pmc}$ in shallow boreholes (Morosini, 1996; Verhagen et al., 1974) indicate that frequent recharge occurs in this aquifer. Water strikes deeper than $100 \mathrm{~m}$ have ${ }^{14} \mathrm{C}$ levels lower than $40 \mathrm{pmc}$ indicating the presence of old, low-nitrate water (Morosini, 1996).

An important feature relevant to the hydrogeology of the Ghanzi area is a fairly general calcrete (caliche) horizon of a few meters thickness. The calcrete is found below the sand at 0-5 $\mathrm{m}$ depth over the entire study area: as it is over much of

\begin{tabular}{|c|c|c|c|}
\hline \multicolumn{4}{|c|}{$\begin{array}{c}\text { Table } 1 \\
\text { Features of the study areas } \\
\text { (data from Tredoux et al., 2005; Tredoux and Talma, } 2006 \text { (Ghanzi); Wrabel, } 2005 \text { (Gobabis); Stadler, } 2005 \text { (Serowe)) }\end{array}$} \\
\hline & Ghanzi & Gobabis & Serowe \\
\hline Size $\left(\mathrm{km}^{2}\right)$ & 100 & 500 & 4090 \\
\hline $\begin{array}{l}\text { Annual precipitation } \\
(\mathrm{mm})\end{array}$ & 420 & $350-400$ & $200-450$ \\
\hline $\begin{array}{l}\text { Potential evaporation } \\
(\mathrm{mm} / \mathrm{a})\end{array}$ & $>3000$ & $>3000$ & in the order of 2000 \\
\hline Lithology & $\begin{array}{l}\text { Aquifer: siliciclastic Ghanzi } \\
\text { Group, overlain by calcrete } \\
\text { and Kalahari sand in places }\end{array}$ & $\begin{array}{l}\text { Aquifer: Kamtsas quartz- } \\
\text { ite overlain by calcrete and } \\
\text { Kalahari sand in places }\end{array}$ & $\begin{array}{l}\text { Aquifer: Triassic Ntane sandstone, con- } \\
\text { fined by the Jurassic Stormberg Basalt, } \\
\text { overlain by Kalahari sand and underlain } \\
\text { by Mosolotsane mudstone layers }\end{array}$ \\
\hline $\begin{array}{l}\text { Average aquifer } \\
\text { thickness (m) }\end{array}$ & $>200$ & around 100 & 100 \\
\hline Aquifer type & Fractured quartzite & Fractured quartzite & Double porosity sandstone \\
\hline $\begin{array}{l}\text { Groundwater levels } \\
\text { (m below surface) }\end{array}$ & $3-40 \mathrm{~m}$ & $\begin{array}{l}\text { Not known, around Farm } \\
\text { Molly: } 10-30 \mathrm{~m} \text {. Elsewhere } \\
\text { unknown. }\end{array}$ & 50 to more than $100 \mathrm{~m}$ \\
\hline Land use & $\begin{array}{l}\text { Extensive cattle grazing on } \\
\text { commercial farms and com- } \\
\text { munal land }\end{array}$ & $\begin{array}{l}\text { Extensive cattle farming } \\
\text { ( } 20 \text { ha/livestock unit) }\end{array}$ & $\begin{array}{l}\text { Extensive cattle grazing }(<11 \mathrm{ha} / \text { live- } \\
\text { stock unit })\end{array}$ \\
\hline Population & $1-10$ persons $/ \mathrm{km}^{2}$ & $<1$ person $/ \mathrm{km}^{2}$ & $<1$ person $/ \mathrm{km}^{2}$ \\
\hline
\end{tabular}


the Kalahari. This calcrete is mature and can be classified as hardpan (Netterberg, 1980). There are occasional fractures in the hardpan which can allow local recharge. In addition, there is clear evidence of erosion features in the hard pans that resemble karstic sinkholes and enable rapid recharge in the immediate area. The sinkholes are usually filled with sand and gravel from the surrounding area but can be easily identified as slight depressions of the surface. They collect surface runoff water during rainstorms and play an important role as recharge conduits. They are generally characterised by a cluster of large trees, contrasting with the surrounding small bushes, indicating the presence and easy accessibility of groundwater in the erosion structure. These erosion features compare well with similar karstic structures in neighbouring Namibia where calcrete overlies basalt at the western edge of the Kalahari, and were shown to play a key role in groundwater recharge (Kirchner et al., 2002). Boreholes drilled inside these depressions generally had lower salinity groundwater than those in the surrounding area, indicating preferential recharge. It was concluded that those erosion features with low salinity water were linked to fault- or fracture zones in the underlying basalt conveying water to deeper-seated permeable formations (Kirchner et al., 2002).

The area is well covered with trees (mainly Acacia species), some shrubs and seasonal grass. The entire Ghanzi Ridge area is a relatively productive cattle area consisting of a few dozen cattle ranches. Boreholes from 4 of these ranches were intensively studied. Cattle roam within each ranch but congregate at the boreholes at least every other day. The result is that high accumulations of animal waste occur just around boreholes and the accompanying urine infiltrates into the soil (Talma et al., 2009). These wastes are potential nitrogen pollution sources since no borehole protection measures are in place. Away from the immediate vicinity of the boreholes, the nitrogen-fixing capability of Acacia species and other plants provides a steady input of nitrogen into the soil, as does the possible waste contribution from roaming animals.

A major rainfall episode centred in the Limpopo Province of South Africa, yet extending well into northern Botswana and Namibia, occurred in February 2000 (NOAA, 2000; Dyson and van Heerden, 2001). Three rainfall stations (Ghanzi town, Oakdene and Farm 72-NK) within $30 \mathrm{~km}$ of the study area recorded rainfalls totalling 612 to $912 \mathrm{~mm}$ for the period January to March 2000, with maxima in February 2000

(Fig. 2a). These extraordinary rainfall amounts were some 240 to $365 \%$ of the long-term means for those same months. The same rainfall episode also affected the area around Gobabis in Namibia, $300 \mathrm{~km}$ westwards (Fig. 2b). This event with its associated flooding caused groundwater levels to rise up to 15 $\mathrm{m}$ within weeks (Tredoux and Talma, 2006) probably up to the calcrete levels in places. Cattle deaths occurred in October 2000. On 5 farms located east, north and west of Ghanzi, 354 animals (mainly pregnant heifers) died, representing between 10 and $20 \%$ of the total livestock numbers on these farms. Veterinarians diagnosed the cause of the mortality as nitrate poisoning caused by high nitrate levels in the animals' drinking water.

An investigation was subsequently launched to delineate high nitrate levels in the local groundwater and to understand this phenomenon (Tredoux et al., 2005; Tredoux and Talma, 2006). Details of the study area are given in Table 1 . The first sampling survey of 13 boreholes on the Ghanzi Ridge in October 2000 showed nitrate levels in local boreholes ranging between 62 and $2250 \mathrm{mg} / \ell$. In the course of 4 follow-up sampling campaigns until 2004, a total of 52 samples for chemical

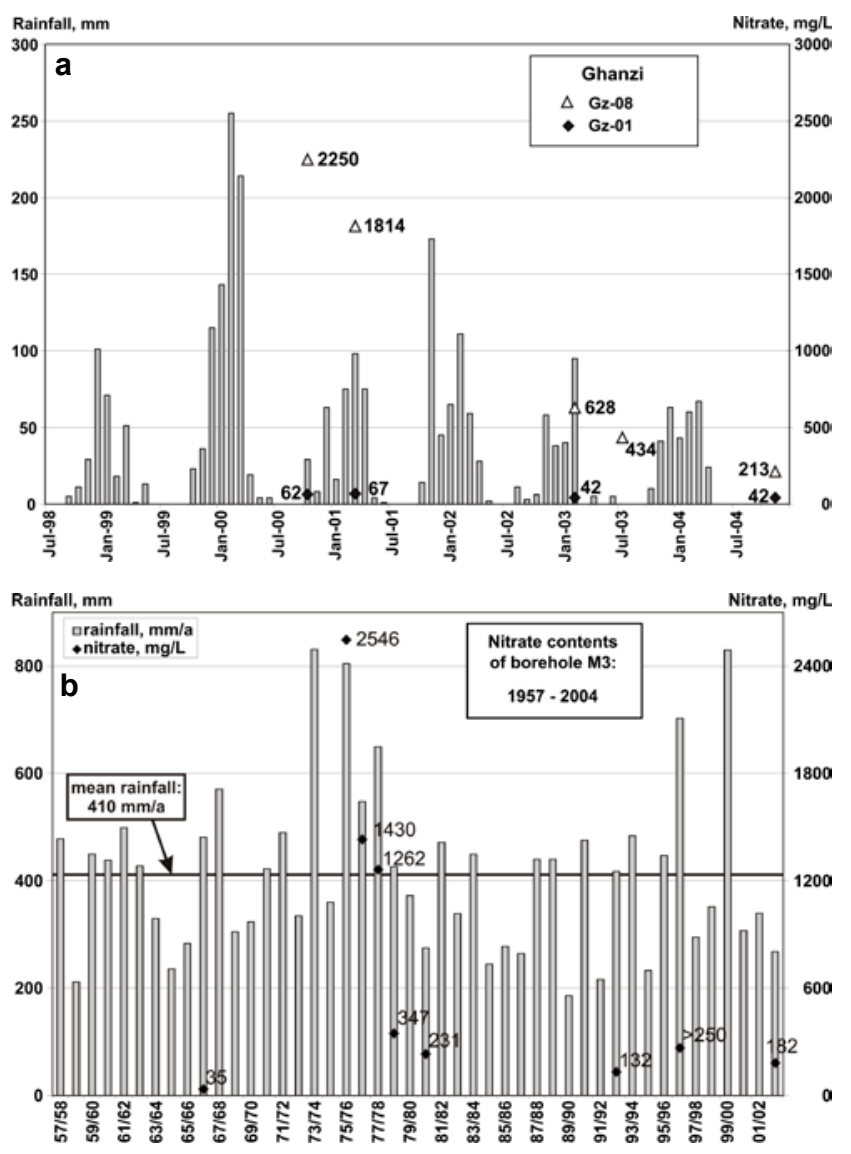

Figure 2

Precipitation ( $\mathrm{mm} / \mathrm{a})$ and nitrate concentrations in groundwater: (a) Ghanzi (Botswana) for boreholes Gz-01 and Gz-08 between 1998 and 2004, and

(b) Gobabis (Namibia) for borehole M3 for 1957 to 2003 Note the scale differences on the nitrate and date axes.

Nitrate $(\mathrm{mg} / \mathrm{L})$

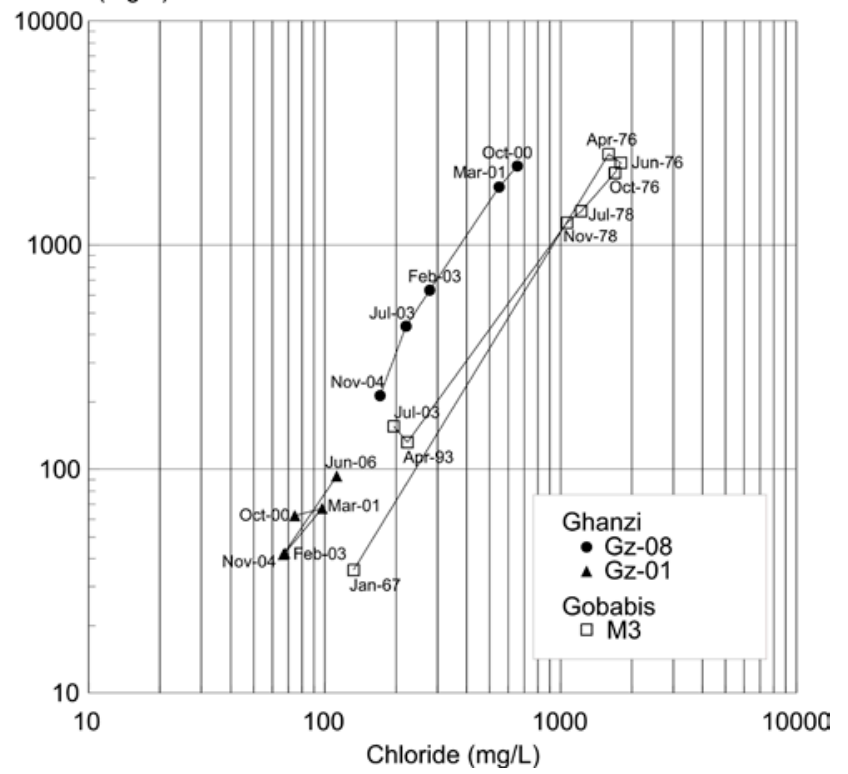

Figure 3

Temporal developments of nitrate versus chloride on selected groundwater sampling points at Ghanzi, Botswana (circles and triangles), and Gobabis, Namibia (squares). Labels represent sampling dates. 
Table 2

Selected water chemistry and ${ }^{15} \mathrm{~N}-\mathrm{NO}_{3}$ and ${ }^{18} \mathrm{O}-\mathrm{NO}_{3}$ data from the 3 study areas

(data from Tredoux et al., 2005; Tredoux and Talma, 2006; Wrabel, 2005; Stadler, 2005; Stadler et al. 2008, 2010a)

\begin{tabular}{|c|c|c|c|c|c|c|c|c|c|c|c|}
\hline Sample ID & Location & $\begin{array}{c}\mathrm{EC} \\
(\mu \mathrm{S} / \mathrm{cm})\end{array}$ & $\begin{array}{c}\mathrm{Ca} \\
(\mathrm{mg} / \mathrm{e})\end{array}$ & $\begin{array}{c}\mathrm{Mg} \\
(\mathrm{mg} / \mathrm{l})\end{array}$ & $\begin{array}{c}\mathrm{Na} \\
(\mathrm{mg} / \mathrm{\ell})\end{array}$ & $\begin{array}{c}\mathrm{Cl} \\
(\mathrm{mg} / \mathrm{l})\end{array}$ & $\begin{array}{c}\mathrm{SO}_{4} \\
(\mathrm{mg} / \mathrm{l})\end{array}$ & $\begin{array}{l}\mathrm{HCO}_{3} \\
(\mathrm{mg} / \mathrm{\ell})\end{array}$ & $\begin{array}{c}\mathrm{NO}_{3} \\
(\mathrm{mg} / \mathrm{l})\end{array}$ & \begin{tabular}{|c|}
$\delta^{15} \mathrm{~N}-\mathrm{NO}_{3}$ \\
$\%{ }^{\circ} \mathrm{AIR}$
\end{tabular} & \begin{tabular}{|l|}
$\delta^{18} \mathrm{O}-\mathrm{NO}_{3}$ \\
$\%$ SMOWW \\
\end{tabular} \\
\hline \multicolumn{12}{|c|}{ GHANZI (Oct 2000) } \\
\hline Gz-01 & De Graaf & 1030 & 86 & 29 & 90 & 75 & 48 & 401 & 62 & +8.3 & +18.4 \\
\hline Gz-02 & De Graaf & 5430 & 233 & 191 & 700 & 520 & 190 & 649 & 1654 & +9.1 & +14.7 \\
\hline Gz-03 & De Graaf & 3620 & 450 & 121 & 125 & 333 & 53 & 373 & 1261 & +10.3 & +12.4 \\
\hline Gz-04 & De Graaf & 3760 & 175 & 162 & 421 & 433 & 179 & 666 & 807 & +10.6 & +15.5 \\
\hline Gz-05 & De Graaf & 3000 & 320 & 145 & 65 & 337 & 87 & 355 & 816 & +13.2 & +13.6 \\
\hline Gz-08 & Lewies & 6900 & 397 & 210 & 635 & 657 & 210 & 442 & 2240 & +9.8 & +13.3 \\
\hline Gz-12 & Lewies & 2790 & 74 & 38 & 510 & 275 & 343 & 601 & 243 & +7.2 & +16.1 \\
\hline Gz-14 & Lewies & 4800 & 414 & 215 & 270 & 385 & 175 & 447 & 1742 & +9.4 & +13.5 \\
\hline \multicolumn{12}{|c|}{ GOBABIS (June 2004) } \\
\hline BB7-GW3 & Babi-Babi & 1801 & 164 & 43 & 132 & 208 & 62 & 281 & 213 & +17.4 & +14.5 \\
\hline D1-GW2 & Dabis & 1665 & 122 & 47 & 135 & 167 & 65 & 199 & 243 & +15.7 & +14.5 \\
\hline D7-GW2 & Dabis & 1061 & 93 & 33 & 81 & 54 & 16 & 411 & 52 & +14.6 & +17.4 \\
\hline M1-GW3 & Molly & 650 & 93 & 11 & 25 & 22 & 14 & 218 & 40 & +14.6 & +12.4 \\
\hline M2-GW1 & Molly & 1508 & 115 & 32 & 137 & 111 & 52 & 360 & 220 & +13.5 & +10.5 \\
\hline M4-GW3 & Molly & 2113 & 151 & 50 & 212 & 308 & 95 & 394 & 161 & +13.5 & +16.3 \\
\hline M5-GW32 & Molly & 1704 & 100 & 39 & 197 & 213 & 53 & 412 & 98 & +11.8 & +11.8 \\
\hline G13-GW1 & Grauwater & 2576 & 187 & 71 & 220 & 319 & 117 & 291 & 355 & +20.3 & +13.3 \\
\hline \multicolumn{12}{|c|}{ SEROWE (2002-2004) } \\
\hline BH 5311 & Serowe & 526 & 22.2 & 11.2 & 81.6 & 45.8 & 9.9 & 252 & 1.7 & +7.8 & +10.3 \\
\hline BH 7005 & Serowe & 560 & 8.7 & 1.0 & 122 & 46.7 & 6.4 & 260 & 5.6 & +8.0 & +7.0 \\
\hline BH 7099 & Serowe & 283 & 7.1 & 1.1 & 58.4 & 13.1 & 2.8 & 154 & 2.6 & +2.8 & \\
\hline BH 7102 & Serowe & 549 & 16.8 & 6.2 & 107 & 27.5 & 14.3 & 286 & 3.8 & +8.2 & +9.7 \\
\hline BH 7021 & Serowe & 645 & 42.5 & 23.7 & 52.6 & 49.4 & 3.1 & 248 & 55.7 & +4.3 & +4.2 \\
\hline BH 8451 & Serowe & 811 & 68.5 & 20.5 & 68.5 & 56.0 & 0.7 & 294 & 103.0 & +4.1 & +5.0 \\
\hline BH 8471 & Serowe & 1207 & 107 & 41.7 & 62.9 & 123 & 1.7 & 293 & 178.0 & +5.1 & +5.2 \\
\hline BH 8480 & Serowe & 554 & 41.1 & 5.4 & 66.3 & 34.5 & 5.6 & 216 & 35.9 & +4.9 & +4.9 \\
\hline BH 8819 & Serowe & 601 & 39.8 & 9.9 & 74.5 & 35.1 & 1.3 & 237 & 68.8 & +4.3 & +5.3 \\
\hline KRS 1 & Serowe & 625 & 68.8 & 19.3 & 24.9 & 80.8 & 0.9 & 214 & 17.9 & +5.5 & +4.0 \\
\hline Mahatane & Serowe & 889 & 77.1 & 34.6 & 44.2 & 111 & 2.9 & 319 & 27.1 & +3.5 & \\
\hline BH 7511 & Serowe & 510 & 41.3 & 12.2 & 50.7 & 35.2 & 2.5 & 237 & 22.5 & +5.7 & +3.3 \\
\hline BH 7591 & Serowe & 515 & 48.6 & 14.3 & 43.2 & 22.5 & 2.4 & 267 & 35.7 & +5.2 & +2.3 \\
\hline BH 8673 & Serowe & 585 & 49.7 & 20.5 & 33.5 & 75.4 & 2.4 & 190 & 31.0 & +5.7 & +5.1 \\
\hline Sanakoma & Serowe & 668 & 69.3 & 18 & 45.8 & 56 & 4.8 & 288 & 33.5 & +6.9 & +5.3 \\
\hline T 545 & Serowe & 714 & 10.9 & 5.8 & 141 & 79.6 & 27.2 & 230 & 0.3 & +6.1 & +3.5 \\
\hline
\end{tabular}

analyses were taken at 27 boreholes, 9 of which were sampled at least 3 times. $\delta^{15} \mathrm{~N}$ was analysed on 28 samples from 23 boreholes, $\delta^{18} \mathrm{O}$ in nitrate was analysed for 8 boreholes and tritium for 7 boreholes. Exemplary results are given in Table 2. The farm boreholes sampled during this study were at most only 40 $m$ deep since the practice is to stop drilling after the first usable water strike. Borehole casings are generally short and seldom extend beyond $6 \mathrm{~m}$ depth, except where thicker layers of unconsolidated material are encountered. Hence, vulnerability of boreholes to pollution from the surface is high.

During the 4 years of sampling, the chemical composition of the major anions $\left(\mathrm{NO}_{3}, \mathrm{Cl}, \mathrm{SO}_{4}\right)$ and cations $(\mathrm{Na}, \mathrm{Ca}, \mathrm{Mg})$ changed significantly, from maxima in October 2000 to lower values later (Figs. 2a and 3, Table 2). The magnitude of the variations of nitrate and the other chemical parameters differ from borehole to borehole, but the relation between the parameters remained essentially constant (Fig. 3), thereby indicating that the variations are caused by blending with low salinity water. Bicarbonate variations were smaller than those of other anions. There were boreholes with comparable water levels and in apparently similar pollution situations that only showed small increases of nitrate and chloride concentrations compared to others, as illustrated in Fig. 3. This would indicate a difference in vulnerability to pollution at various points, linked to the local hydrogeology and recharge mechanisms. Apparent pollution point sources include the congregation of animals at watering points, as well as septic tanks with associated drains at homesteads.

${ }^{15} \mathrm{~N}$ analyses showed lower $\delta^{15} \mathrm{~N}(+4$ to $+8 \%$ ) for groundwater with lower nitrate levels $(<80 \mathrm{mg} / \ell)$, while higher $\delta^{15} \mathrm{~N}$ ( +8 to $+14 \%$ ) was found associated with both high and low $\mathrm{NO}_{3}$ content (Table 2, Fig. 4). Repeat analysis of $\delta^{15} \mathrm{~N}^{-N}{ }_{3}$ sampling of 9 boreholes between 2000 and 2003 showed that the standard deviation of these triplicates averaged $0.6 \%$. In borehole 

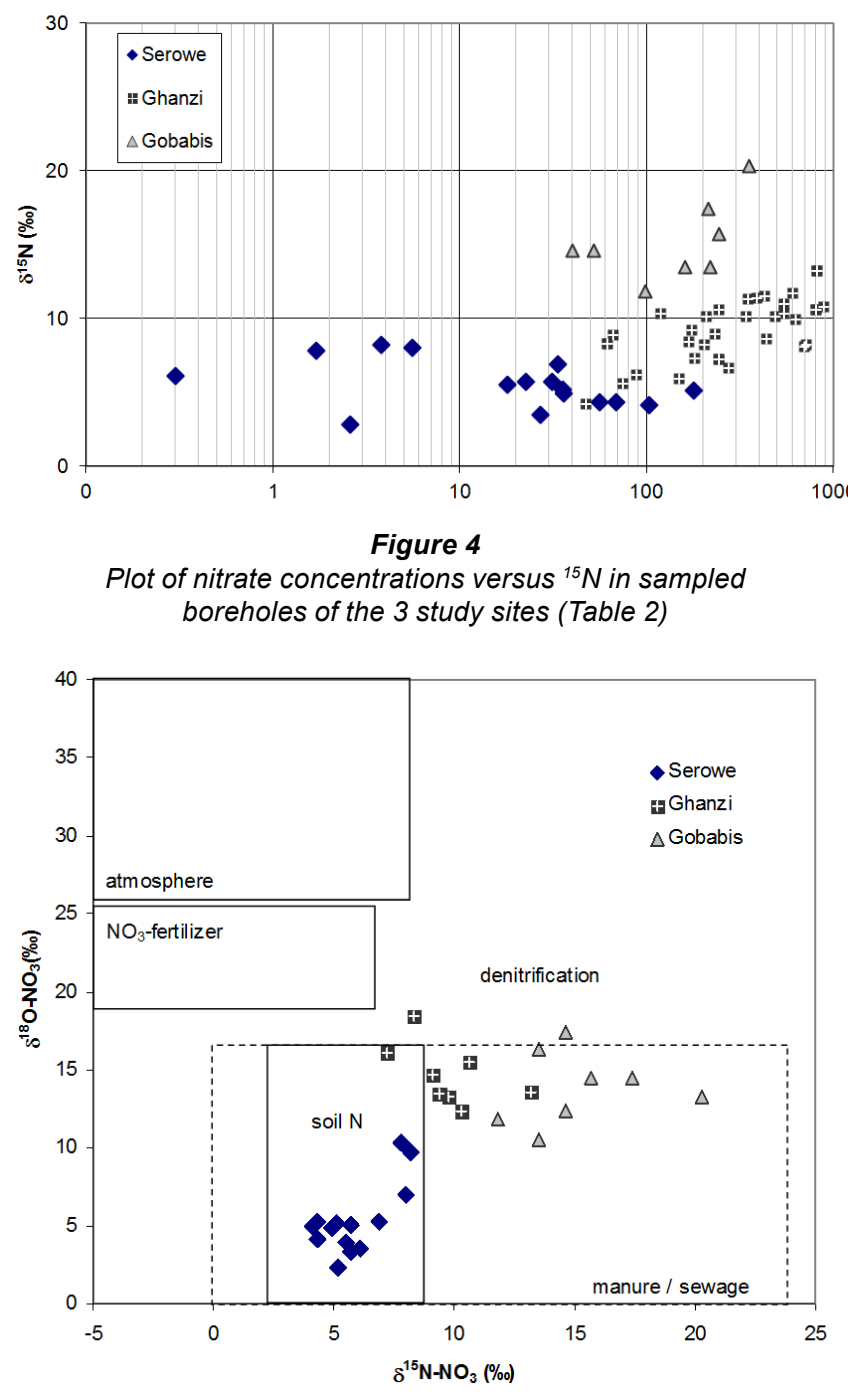

Figure 5

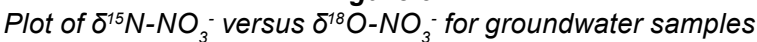
from the 3 study sites: Ghanzi, Gobabis, Serowe.

The fields represent typical ranges of major nitrate sources found elsewhere (from Kendall, 1998). The denitrification arrow indicates the slope of the 2 isotope ratios during denitrification of nitrate.

Gz05 with the largest standard deviation (1.3\%) the mass balance suggested a mixture between high ${ }^{15} \mathrm{~N} /$ high $\mathrm{NO}_{3}$ and low ${ }^{15} \mathrm{~N} /$ low $\mathrm{NO}_{3}$. In all other cases, even with nitrate concentrations changing over a factor of 2 or more, no significant mixing or denitrification trends could be identified within the small ${ }^{15} \mathrm{~N}$ differences (Table 2). The nitrogen source for these 8 boreholes therefore did not change significantly in the course of 3 years. There was a negative correlation between $\delta^{15} \mathrm{~N}$ and $\delta^{18} \mathrm{O}$ (Fig. $5)$. This correlation has been interpreted as suggesting that the low- ${ }^{15} \mathrm{~N}$ nitrate that was formed from natural and dispersed sources used a larger proportion of atmospheric oxygen than the high ${ }^{15} \mathrm{~N}$ pollution which is derived from concentrated cattle manure occurrences and formed under the moist conditions at drinking troughs surrounding boreholes (Tredoux and Talma, 2006). A positive correlation would have suggested that denitrification was occurring (Kendall, 1998), which is unlikely since the presence of dissolved oxygen (1-6 $\mathrm{mg} / \ell$; independent of nitrate content) at most of the boreholes, and the absence of

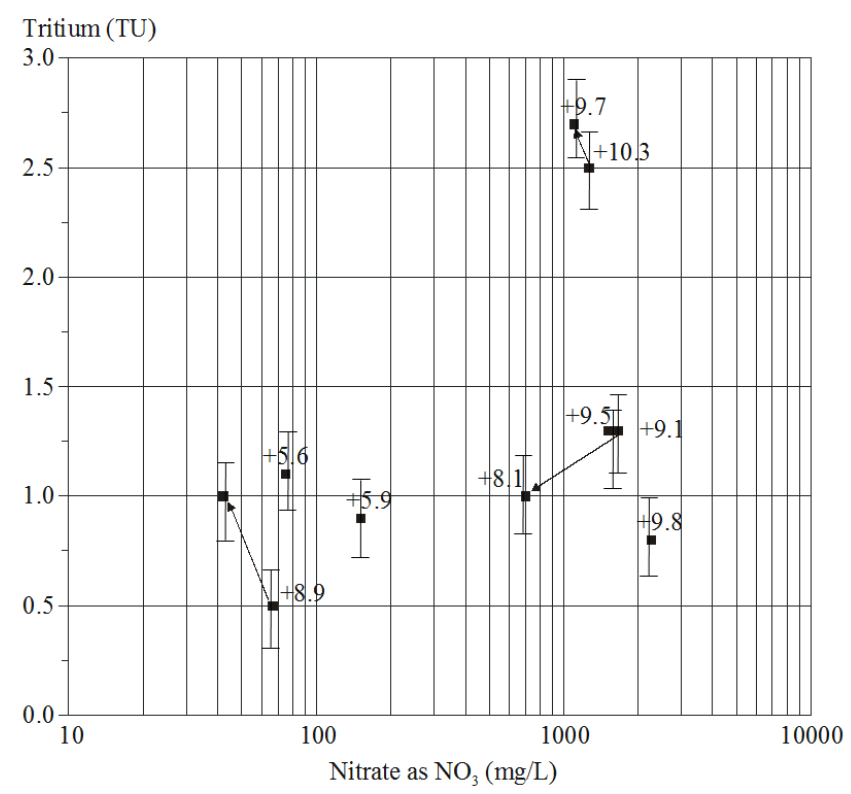

Figure 6

Tritium concentrations versus nitrate in groundwater at Ghanz in 2000 and 2003. The $\delta^{15} \mathrm{~N}$ value is shown where available. The arrows connect data points for boreholes measured both in 2000 and in 2003.

any $\mathrm{NH}_{4}$ and $\mathrm{Mn}$ in the water samples, indicates well-oxidised conditions overall. Nitrate in the Ghanzi groundwater therefore seems to behave conservatively and the main cause for variation in its concentration is dilution with low salinity water.

Tritium analyses were done in order to get an idea of water turnover times. Present day tritium contents in southern Africa are 1.5 - 4 TU (GNIP (2011): data for Harare 1998-2001). For 6 of the 7 boreholes, tritium contents between 0.5 and $1.5 \mathrm{TU}$ values (Fig. 6) indicate that some component (but not all) of post-1960 recharge is found in the groundwater samples that were analysed and suggests rapid recharge throughout the area. Non-zero tritium in samples analysed during the present study (Fig. 6), as well as ${ }^{14} \mathrm{C}$ values of 80 to $90 \mathrm{pmc}$ (Morosini, 1996), confirm that frequent recharge occurs in this aquifer. Nevertheless, the tritium results show that more than $50 \%$ of the groundwater in the aquifer is pre-1960 recharge.

Since all the boreholes are equipped with pre-installed pumps, only limited possibilities existed for measuring borehole or water table depths; information on water strikes is also not available. Consequently it was not possible to test an association of water nitrate concentrations with depth of the water table or water strike in the farming area. The existence of high cattle density around a particular borehole (as is frequently the case) did not necessarily result in higher nitrate levels in the groundwater of the specific point, despite significant animal waste accumulation observed on the surface. In other instances both the animal waste accumulation and the outflow from septic tanks could have caused high nitrate levels.

The sudden increase and subsequent slow decrease of salinity, nitrate and water level during 2000-2004 indicates that 2 water types have to be considered: fresh and saline. It is postulated that the variable transmissivity of the 0-5 m deep calcrete layer throughout most of the area, together with the varying thickness of the sand cover, causes these variations. During average rainfall years the water table response to rainfall is known to be small (Tredoux et al., 2005; Tredoux and Talma, 


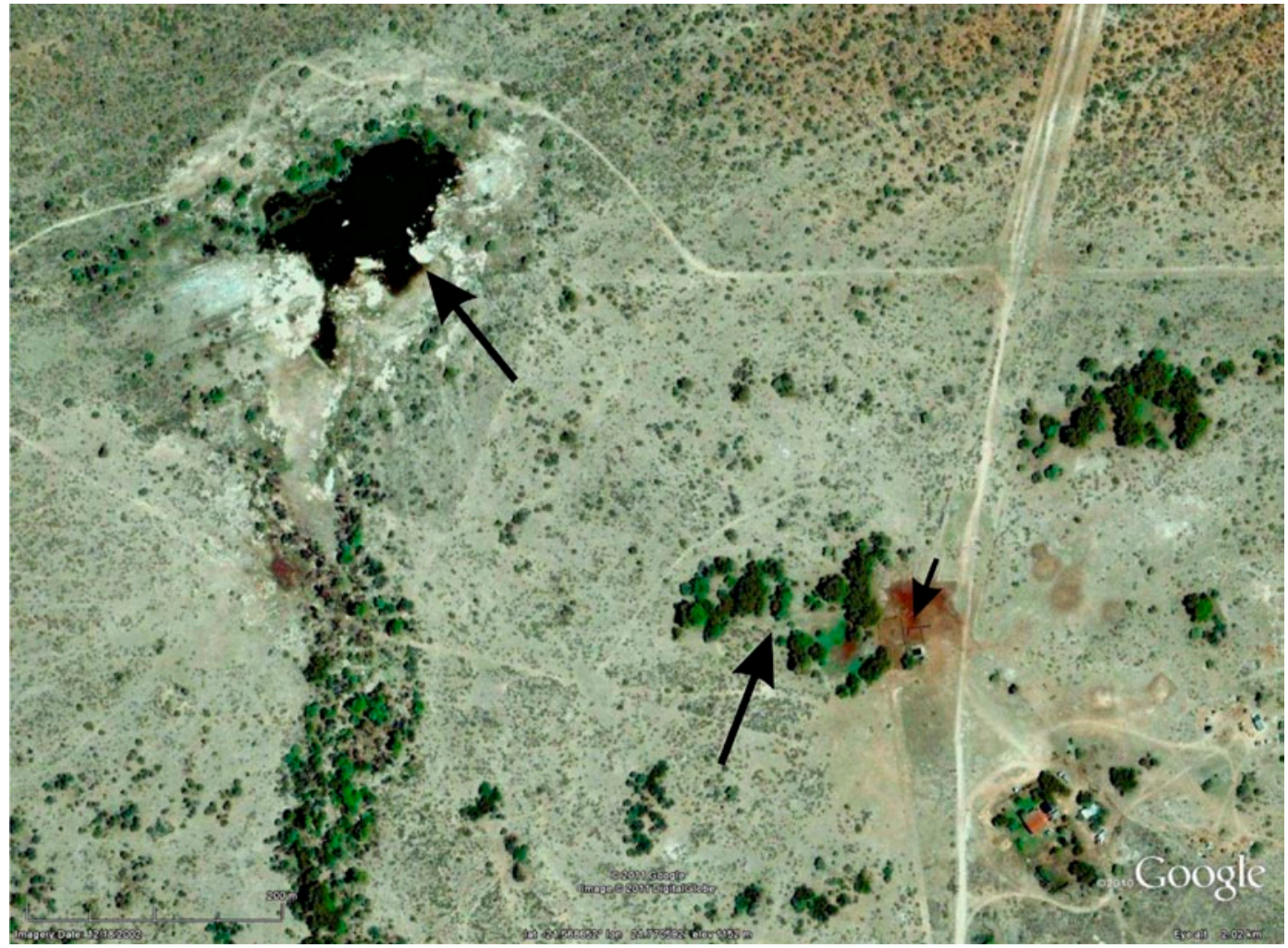

Figure 7

Sinkholes in the calcrete $19 \mathrm{~km}$ north-east of Ghanzi. The larger arrows point to the sinkhole structures with the smaller arrow indicating a kraal near one of the sinkholes (Satellite images taken on 18 December 2002 and published in Google Earth)

2006). In areas of good vertical connection provided by eroded parts of the calcrete (so-called sinkholes: Fig. 7) and linked to fractures in the quartzite, groundwater will be recharged to below the calcrete layer with little or no salt build-up. Partially perched water tables will form in those parts where the calcrete layer is less permeable. During the dry season, this perched water will be extracted by the deep-rooted trees causing a build-up of salinity in the local vadose zone (Talma et al., 2009; Walvoord et al., 2003). Local pollution (mainly cattle manure) and nitrate produced by nitrogen-fixing vegetation will be added to the salt load in the soil during these 'normal' rainfall years. The kraal next to one of the sinkholes shown in the satellite image in Fig. 7 illustrates the groundwater pollution potential in the Ghanzi area.

Following the exceptional rainfall of 2000, large areas were flooded and standing surface water was visible for weeks. The resultant rapid recharge caused the salt load located in the soil to be flushed towards the nearest infiltration zone. This salty, nitrate-loaded water would then have been encountered in the localities of rapid infiltration and also found in some of the boreholes which are generally shallow and only cased for the top few metres. It is postulated that during the subsequent years (2000-2004) the layer of recently infiltrated nitratebearing water was removed by pumping. Progressive dilution with deeper groundwater of lower salinity during abstraction caused the ion levels to drop off accordingly (Figs. 2a and 3). As the farmers at present rely on shallow boreholes for their stock watering, their animals are very vulnerable to the consequences of the salinity and nitrate peaks after such high rainfall events.

\section{Gobabis District, Namibia}

In the Gobabis district, $300 \mathrm{~km}$ west of Ghanzi across the Namibian border (Fig. 1), groundwater is found in the Kamtsas
Formation (the western extension of the Ghanzi Ridge of Botswana). Although the topography in the Gobabis District differs from that in the Ghanzi area due to the presence of greater landscape undulations and distinct drainage systems, such as the ephemeral Chapman River, the hydrogeology of the bedrock is similar (Table 1). In the sand- and calcrete-covered areas, the groundwater recharge processes appear to closely resemble those of Ghanzi groundwater. As in Botswana, the farmers generally do not drill deeper than necessary to ensure a suitable water supply for household and stock watering. Hence most boreholes are shallow and casings are only provided to protect the top part of the borehole from caving in. The length of the casings seldom exceeds $6 \mathrm{~m}$ and could be as little as $3 \mathrm{~m}$.

Nitrate concentrations in boreholes of the Gobabis area have been monitored by the Department of Water Affairs of Namibia from as early as 1967 and are known to be high (Heaton, 1984; Huyser, 1982). Cattle deaths have been reported in the area following a high rainfall period between 1974 and 1976 which was followed by higher nitrate levels in some boreholes (Fig. 2b). The area also experienced the effect of high rainfall in 2000, similar to Ghanzi, and the subsequent increases in groundwater nitrate levels (Fig. 2b).

Samples from 35 boreholes over the $500 \mathrm{~km}^{2}$ area analysed between 1967 and 2004 showed nitrate levels in groundwater to vary between 10 and $2546 \mathrm{mg} / \ell$ (Wrabel, 2005 and Figs. 2b, 3 and 6 and Table 2). The highest nitrate levels in the area were found associated with quartzite outcrops (Wrabel, 2005). In addition to the wide spatial distribution ranges, strong temporal concentration changes were found, for example, at borehole M3 (Farm Molly) an increase in nitrate concentrations from 35 to $2520 \mathrm{mg} / \ell$ followed on 2 seasons (1973/4 and 1975/6) of twice the mean annual rainfall (Fig. 2b). Five years later, the nitrate levels in this particular borehole had decreased to $231 \mathrm{mg} / \ell$. These changes in nitrate concentrations were accompanied by parallel changes in the chloride concentration (Fig. 3). This 
particular borehole is located within $150 \mathrm{~m}$ of the ephemeral Chapmans River which ensures groundwater recharge during flood events, albeit at infrequent intervals. Similar to the situation in Ghanzi, the rapid water quality deterioration after heavy rainfall (Fig. 2b) indicates the direct effect of flood water recharge in areas where nitrates and other salts have accumulated, and a quick groundwater turnover with relatively short residence times.

During 2003/4, the monitoring included sampling for stable isotopes in nitrate (Wrabel, 2005). $\delta^{15} \mathrm{~N}$ of the measured groundwater samples range from +11.8 to $+20.3 \%$ (mean $+15.2 \%$ ). $\delta^{18} \mathrm{O}$ values lie between +10.5 and $+17.4 \%$ (mean $+13.8 \%$ \% (Fig. 5 and Table 2). The more positive ${ }^{15} \mathrm{~N}$ and ${ }^{18} \mathrm{O}$ data (Fig. 5 ) indicate that some denitrification could have taken place. These isotope values cannot be interpreted as uniquely resulting from either the impact of nitrate pollution from the waste of cattle congregating at the boreholes, or nitrogen derived from local vegetation. Dissolved organic carbon values of $1-3 \mathrm{mg} / \ell$ in these same samples suggest pollution (e.g. from manure) and that denitrification could be possible, yet manganese values of $<0.02 \mathrm{mg} / \ell$ (the only additionally available potential redox indicator measured at this borehole) do not support the required reducing conditions.

The main difference between Ghanzi and Gobabis is the considerably higher chloride concentrations at Gobabis, which is presumed to be an attribute related to the presence of the river drainage system where more evaporation may take place. The similarity of geology and hydrological responses produced similar temporal nitrate variations (Figs. $2 b$ and 3 ), and is of concern for the local cattle industry.

\section{Serowe, Botswana}

The Central District of Botswana, centred on the town of Serowe (Fig. 1), is located on the eastern fringe of the Kalahari. At an elevation of about $1200 \mathrm{~m}$ above mean sea level, the area has a flat, slightly undulating topography. Soil and plant cover are similar to the setting observed in the Ghanzi study area. Permanent surface waters are absent. The area is scarcely inhabited, and is used for extensive cattle grazing (Table 1). Groundwater levels are 50 to $100 \mathrm{~m}$ below the surface, and nitrate concentrations of up to $219 \mathrm{mg} / \ell$ were found in the water. Groundwater was sampled from the Ntane Sandstone aquifer from production and observation boreholes that are generally screened over almost the entire aquifer thickness (for details see Stadler et al., 2008 and Stadler et al., 2010b). The Ntane Sandstone aquifer is an aeolian sandstone with a porosity controlled by intergranular voids (primary porosity) and fractures and fissures (secondary porosity). It is overlain by the Stormberg Basalt, which in turn is covered by several tens of meters of Kalahari Sands. The Stormberg Basalt regionally behaves as a confining aquiclude, but locally can possess enhanced fracture-induced permeability, creating a hydraulic connection to the Ntane sandstone. Being a flood basalt, it unconformably overlays the Ntane sandstone, filling depressions of the former morphology. Due to the complex structural setting, local windows in the basalt are present, where the Ntane sandstone is exposed and directly overlain by Kalahari sands. Calcretes, as described in the Ghanzi section, have been reported to occur in the area, but do not appear to be of major hydraulic significance in this study area (Stadler, 2005).

The investigation in this area involved hydrochemical sampling of 51 boreholes near Serowe (Stadler et al., 2008). A detailed hydrogeochemical description of this study area can be found in Stadler et al. (2010a, 2008) and Stadler (2005). Exemplary results are given in Table 2 .

In Serowe nitrate concentrations in groundwater between 0 and $219 \mathrm{mg} / \ell$ were measured (Table 2 ). Although the nitrate concentrations are not normally distributed (mean: $23 \mathrm{mg} / \ell$, median: $8 \mathrm{mg} / \ell), \delta^{15} \mathrm{~N}^{-\mathrm{NO}_{3}}{ }^{-}$values are clustered quite narrowly in a range of +2.8 to $+8.2 \%$ (mean: $+5.4 \%$ ) (Figs. 4 and 5). $\delta^{18} \mathrm{O}-\mathrm{NO}_{3}{ }^{-}$values lie between +2.3 and $+10.3 \%$ (mean: $+7.1 \%$ ) (Fig. 4). These values are attributed to active involvement of the nitrogen found in the groundwater in the natural soil nitrogen cycle (Stadler et al., 2008)) and subsequent leaching from this non-anthropogenic nitrogen pool towards the groundwater. Considering the prevailing hydrochemistry, the isotopic fractionation of ${ }^{15} \mathrm{~N}$ and ${ }^{18} \mathrm{O}$ in the nitrate, the slow travel times of water through the unsaturated zone, the short recent time-span of land-use for cattle grazing, and the lack of detectable $\mathrm{NH}_{4}$ and $E$. coli in the groundwater samples, there are no indications of the impact of animal waste through land-use (Stadler et al., 2008). In addition, no clear relation of nitrate with chloride was found in the groundwater that could have reflected evaporative enrichment of nitrate (or contamination) (Stadler, 2005). Chloride concentrations in the groundwater are quite low (mean: $60 \mathrm{mg} / \ell$ ). Another indication, at least for the absence of open water body evaporation (prior to infiltration), is given by ${ }^{2} \mathrm{H}$ and ${ }^{18} \mathrm{O}$ of the same water (Stadler et al., 2008), as the measured values lie on the meteoric water line. The measured ${ }^{2} \mathrm{H}$ and ${ }^{18} \mathrm{O}$ data can however not provide information on any potential evaporation below the surface.

In contrast to the quick-response flow system of Ghanzi and Gobabis, the Serowe aquifer system is a long-term slowresponse system, where nitrate concentrations are associated with differences in groundwater residence times and a change in recharge conditions on a timescale of several thousand years. This conclusion is based on the application of a broad range of environmental tracers $\left({ }^{3} \mathrm{H}, \mathrm{CFC}, \mathrm{SF},{ }^{3} \mathrm{He},{ }^{4} \mathrm{He},{ }^{20} \mathrm{Ne},{ }^{22} \mathrm{Ne}\right)$ coupled with hydrochemical investigations (Stadler, 2005; Stadler et al., 2008; Osenbrück et al., 2009). The relating studies are summarized in the following: The analysis of groundwater from Serowe revealed only minor active groundwater recharge occurring under present semi-arid conditions (Stadler et al., $2008 ; 2010$ b). This was based on detectable amounts of CFCs and $\mathrm{SF}_{6}$ in the groundwater that significantly exceed concentrations in equilibrium with the atmosphere, and also exceed concentrations that could have entered the aquifer by diffusion. The concurring low ${ }^{3} \mathrm{H}$ levels $(<0.3 \mathrm{TU})$ would generally point to the absence of recharge and indicate minimum travel times of the water of greater than 50 years. However, these studies support that the 2 tracer types, gas and solute tracers, yield different information regarding water transport and reveal differences of transport in the unsaturated and saturated zones, respectively. While solute tracers like ${ }^{3} \mathrm{H}$ are moved advectively with the seepage water (and may decay on the way), gas tracers like $\mathrm{CFC}$ and $\mathrm{SF}_{6}$ pass the unsaturated zone relatively fast though the air phase and 'set their clock' at the groundwater table. Regarding nitrate concentrations the authors suggest that the present land-use does not appear to affect nitrate concentrations in groundwater yet. This was mainly based on the only minor recharge amounts, on calculated minimum travel times of water exceeding 50 years by far for a major groundwater fraction, and on the fact that the area has only been used for extensive cattle grazing for about the past 50 years.

Using excess air as a proxy allowed reconstructing present and palaeo-infiltration conditions in the same Serowe study area (Osenbrück et al., 2009). Excess air dissolved in 
groundwater describes the super-saturation of dissolved atmospheric gases in groundwater with respect to the equilibrium concentration (Heaton and Vogel, 1981). It hence reflects conditions and processes during groundwater recharge (AeschbachHertig et al., 2000). Osenbrück et al., (2009) found that elevated amounts of excess air occurred in some of the investigated water, as revealed by neon concentration and neon isotope measurements, yielding Ne concentrations between 1.6 to 2.9 $10^{-7} \mathrm{~cm}^{3} \mathrm{STP} / \mathrm{g}$. This Ne, i.e. excess air and hence recharge rate proxy, correlates with nitrate concentrations measured in the groundwater (Fig. 8a). Water with high nitrate concentrations was recharged under drier (semi-arid) conditions while lower nitrate concentrations appear to be the product of recharge under much wetter conditions. It is suggested that in this area the nitrate differences in groundwater are related to climatic change, as observed residence time differences lie within the ranges of past wetter phases.

To obtain the range of groundwater residence times in the Ntane sandstone aquifer, ${ }^{14} \mathrm{C}$ of dissolved inorganic carbon was applied as a residence time indicator, supported by helium isotopes $\left({ }^{3} \mathrm{He}\right.$ and ${ }^{4} \mathrm{He}$ ) for qualitative age estimation (Stadler, 2005; Osenbrück et al., 2009). Using these proxies as indicators for residence times, a relation to nitrate concentrations and groundwater residence times could be found for Serowe (Figs. 8a and 8b), where high nitrate concentrations are connected to lower residence times while low nitrate concentrations are connected to high residence times. As shown in Stadler et al. (2008) this is not related to denitrification, but rather to a difference in input concentrations.

\section{A conceptual model of nitrate input to the groundwater}

The 3 examples of nitrate behaviour described above suggest that 2 quite different scenarios may explain the elevated nitrate concentrations in groundwater of the Kalahari. The scenarios describe how nitrate levels in groundwater and the associated geochemical parameters can be determined by water table depth, recharge rates, rainfall periodicity and groundwater residence times. They are summarised using the examples of Ghanzi and Gobabis as representative of a fast through-flow situation with anthropogenic input conditions (Fig. 9a), and Serowe as representative of a slow through-flow situation under natural conditions (Fig. 9b).

In the fast through-flow scenario (Fig. 9a) the vadose zone is shallow and perched water tables may temporarily exist above the most impermeable parts of the calcrete layer. During the (summer) rainfall season the shallow soil is moistened. During the subsequent dry seasons, the moisture will be removed again by evapotranspiration from the soil or via the tree roots that go down to the calcrete horizons. Because of the total removal of moisture during years of average rainfall, a build-up of salt (including a nitrogen pool) will occur in the unsaturated zone. Only in so-called sinkholes (dissolution breaks in the continuity of the calcrete) will moisture be able to move deeper and actually recharge groundwater on a regular basis. This low recharge (maybe only a few $\mathrm{mm} / \mathrm{a}$ ) will produce a moderate, baseline nitrate content due to plant fixation of nitrogen and faecal pollution.

Heavy seasonal rainfall (typically twice the annual mean) may occur every 10 to 20 years (Fig. 2). During such events, water collects on the surface causing saturation of the soil down to a few metres' depth. There is no local surface drainage and the water either evaporates or recharges the groundwater
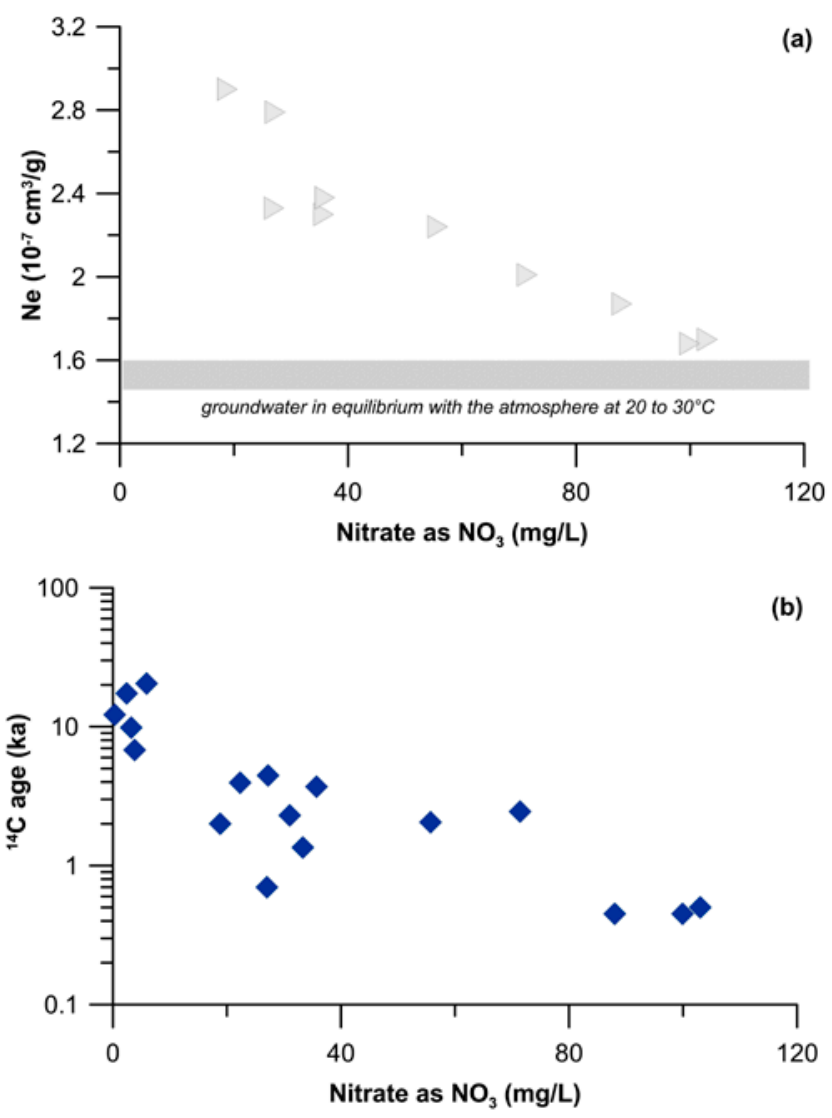

Figure 8

Relations of neon concentrations to nitrate concentrations in groundwater from Serowe. The dashed area indicates the equilibrium concentrations in air-saturated water for the given altitude of the study area (1 $200 \mathrm{~m}$ a.m.s.l.). Lower neon concentrations indicate recharge under more arid conditions.

(b) Calculated ${ }^{14} \mathrm{C}$ ages from Osenbrück et al. (2009) versus nitrate concentrations in groundwater from Serowe.

extensively. Groundwater levels subsequently rise rapidly and the salt pool (including nitrate) that has built up during the preceding dry years is flushed into the groundwater, even requiring some horizontal flow along the calcrete horizons towards more permeable zones. Those boreholes that are near non-leached depressions will therefore exhibit a rapid salinity increase, as was observed in Ghanzi and Gobabis in late 2000. In the subsequent years, mixing of water between pockets of high and low salinity will reduce the salinity (and nitrate) content of the high nitrate boreholes and produce the patterns shown in Figs. 2 and 3. Boreholes away from such local recharge zones may be affected less, showing constant salinity over time. The generally shallow boreholes of the farming areas only utilise the upper zone of the aquifer, subjecting agricultural practices to the hazards of the extreme water quality variations in this part of the aquifer.

The slow through-flow scenario (Fig. 9b), on the other hand, occurs in areas with deep vadose zones as well as deep aquifers, resulting in groundwater with long infiltration times through the unsaturated zone and high residence times in the saturated zone. The example is the case study at Serowe in Central Botswana. The long residence time-scale of groundwater found in this aquifer requires that past pluvial events need to be considered. During Holocene times (ages 0.9 to $5.8 \mathrm{ka}$ ) conditions were relatively dry, while during the Pleistocene 
a)

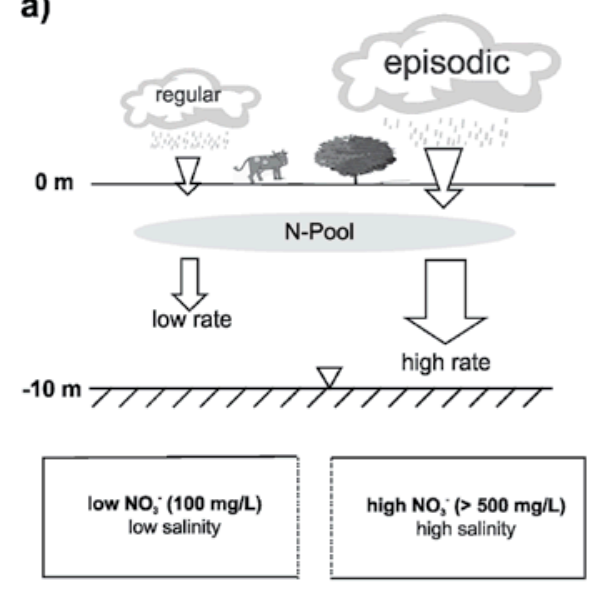

b)

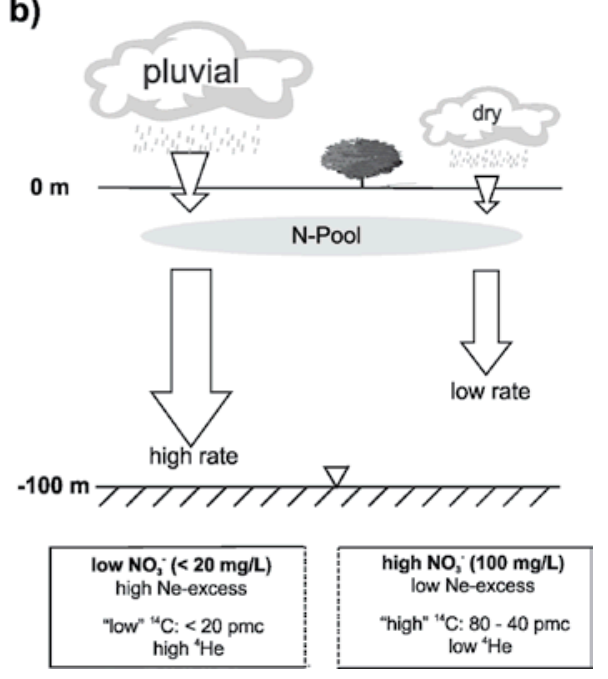

Figure 9

Scheme of the nitrate dynamics in the different study areas with (a) FAST through-flow type and (b) SLOW through-flow type $\left({ }^{14} \mathrm{C}\right.$ content $<20$ pmc in Fig. 8 b) periods of high rainfall have been identified (Thomas and Shaw, 2002). The (relatively) low recharge produces higher nitrate levels and low neon excess (low excess air) (Fig. 8b). Periods of higher recharge result in shallower groundwater tables and in a more rapid mobilisation and dilution of the nitrogen pool in the vadose zone, and thus lower nitrate levels in groundwater. Such higher rainfalls can generate high neon excesses because under increased hydrostatic pressure air is trapped during frequent recharge events. Water recharged during the Pleistocene is characterised by low ${ }^{14} \mathrm{C}$ content $(<20 \mathrm{pmc})$ (Fig. 8 b).

The role of the calcretes in this particular scenario cannot be identified. Yet it is assumed that they either play a minor role as designated in Stadler (2005), or that their impact is masked by other processes. This could be the long travel times through the thick unsaturated zone extending to $100 \mathrm{~m}$ or an impact of the basalt, which might buffer short-term responses of the water level to heavy rainfall. However, observations similar to those in Ghanzi and Gobabis have not even been reported for areas where windows in the basalt are present, which should be the case if the basalt plays a significant role (Stadler et al., 2008). Else, the long screen lengths of the boreholes, mainly over the entire aquifer thickness, may play a role, as this gives an integral signal over the full aquifer thickness - while shallow processes may be obscured through mixing and potential rapid responses to extreme rainfalls are averaged out by the time the water is pumped out - an issue which is, however, not scenario-specific.

\section{Conclusions}

Two of the three investigated sites (Ghanzi and Gobabis) were polluted through cattle grazing and resulting manure, where nitrate (and salinity) increases in the shallow groundwater can be triggered by excessive rainfall events (fast through-flow scenario). In contrast, one site (Serowe) showed that nitrate concentrations in the groundwater were of natural origin related to slow mobilisation of nitrate pools existing in the deep unsaturated zone, and the concentrations are a function of climatic developments and associated changes in recharge conditions (slow through-flow scenario). There, nitrate concentrations are higher in recent groundwater from the present semi-arid conditions.

Although the nitrate levels found in the slow recharge scenario may not be as high as the ones observed under extreme pollution events, they still by far exceed the WHO guidelines for drinking water and may have serious long-term health implications. This is an observation which is of importance for semi-arid areas, and implies that presently observed nitrate concentrations do not necessarily reflect the impact of presentday land use alone. The effects of present-day land use may only manifest after decades. Localised nitrogen pollution spots exist in the shallow soil zone below a depth that is affected by contribution and withdrawal of $\mathrm{N}$ by soil flora and fauna in Serowe (Schwiede, 2007), and it is only a matter of time (and flushing) for this pollution to reach the water table. This is in accordance with Walvoord et al. (2003), who have also identified substantial amounts of nitrogen, from the soil pool below the root zone in semi-arid to arid regions, which can be leached downwards during high-recharge events.

The Ghanzi and Gobabis situations highlight an important limitation on the use of groundwater for stock watering. Under the conditions prevailing in these areas, water that is generally suitable for stock watering can become poisonous to livestock within a very short period of time (e.g. months). Animals cannot adapt that fast and therefore fatalities occur. As the Ghanzi Group/Kamtsas Formation forms a secondary aquifer with a relatively shallow water table and a high permeability, attenuation of pollutants in the subsurface is very limited. The Botswana National Ground Water Pollution Vulnerability Map (Busch et al., 1995) aptly rates the vulnerability of most of the Ghanzi Ridge as 'moderate' to 'high'. The pollution episode of 2000 has proven that statement to be very appropriate. In the type of situation represented by the Ghanzi and Gobabis examples, a short-term solution for farmers would be to drill boreholes deeper and case them off for more than just the upper few meters, as is the present practice. Remediation would consist either of removal of the pollution sources from the vicinity of the boreholes and sinkholes in the area, or establishing criteria to locate boreholes in localities away from the pollution source. Whereas relocation of the boreholes will yield immediate, though not necessarily long-term, results, removal of pollution sources may take longer to yield the desired result.

\section{Acknowledgements}

The authors acknowledge the support of Horst Vogel, Michael von Hoyer and Greg Christelis, who facilitated the cooperation between Botswana, Namibia and South Africa for groundwater 
nitrate studies to become a reality. Scientific interaction with Pannie Engelbrecht, Thomas Himmelsbach, Heinz Hötzl, Wim Duijnisveld, Karsten Osenbrück and Stephan Weise, and anonymous reviewers (for this and earlier versions of the paper), helped us to clarify our ideas. Logistical support for the individual projects was supplied by DGS, DWA and Debswana in Botswana, MAWF in Namibia, and BGR in Germany. Isotope analyses were done by CSIR (Pretoria, South Africa), Hydroisotop (Munich, Germany) and Helmholtz-Centre for Environmental Research-UFZ (Leipzig-Halle, Germany). Noble gas analyses were done at the University of Bremen (Germany). Financial support was provided by CSIR, the Water Research Commission WRC and Department of Science and Technology (South Africa), MAWF (Namibia) and BGR (Germany). Chemical analyses were done and funded by CSIR (Stellenbosch, South Africa), MAWF (Windhoek, Namibia) and BGR (Hannover, Germany).

\section{References}

ADDISCOTT TM, WHITMORE AP and POWLSEN DS (1991) Farming, Fertilizers and the Nitrate Problem. CAB International, Wallingford. $170 \mathrm{pp}$.

AESCHBACH-HERTIG W, PEETERS F, BEYERLE U and KIPFER $R$ (2000) Palaeotemperature reconstruction from noble gases in ground water taking into account equilibration with entrapped air. Nature 405 1040-1044.

ANAYAH FM and ALMASRI MN (2009) Trends and occurrences of nitrate in the groundwater of the West Bank, Palestine. Appl. Geogr. 29 (4) 588-601.

BARNES CJ, JACOBSEN G and SMITH GD (1992) The origin of high nitrate ground waters in the Australian arid zone. J. Hydrol. 137 181-197.

BÖHLKE JK (2002) Groundwater recharge and agricultural contamination. Hydrogeol. J. 10 153-179.

BUSCH K, VON HOYER M, MABUA K and MOKOKWE K (1995) Groundwater pollution vulnerability map of Botswana $<1: 1000000>$. Dept. Geol. Surv., Lobatse, Botswana.

CANTER LW (1997) Nitrates in Groundwater. CRC Press Inc., Boca Raton. 263 pp.

CARLSON JR and BREEZE R G (1984) Ruminal metabolism of plant toxins with emphasis on indolic compounds. J. Anim. Sci. 58 1040-1049.

DE VRIES JJ (1984) Holocene depletion and active recharge of the Kalahari groundwaters: a review and an indicative model. $J$. Hydrol. 70 221-232.

DE VRIES JJ and SIMMERS I (2002) Groundwater recharge: an overview of processes and challenges. Hydrogeol. J. 10 5-17.

DWAF (DEPARTMENT OF WATER AFFAIRS AND FORESTRY, SOUTH AFRICA) (1996) South African Water Quality Guidelines. Volume 5. Agricultural Use: Livestock Watering. URL: http:// www.dwaf.gov.za/iwqs/wq guide/Pol saWOguideFRESH vol5 Livestockwatering.pdf (Accessed 12 Dec 2010).

DYSON LL and VAN HEERDEN J (2001) The heavy rainfall and floods over the north-eastern interior of South Africa during February 2000. S. Afr. J. Sci. 97 80-86.

EDMUNDS WM and GAYE CB (1997) Naturally high nitrate concentrations in groundwaters from the Sahel. J. Environ. Qual. 26 1231-1239.

FAVREAU G, LEDUC C, SEIDEL JL, OUSMANE SD and MARIOTTI A (2003) Land clearance and nitrate-rich groundwater in a Sahelian aquifer, Niger. In: Proc. Hydrology of the Mediterranean and Semiarid Regions, Montpellier, April 2003, 163-167. IAHS Publ. No. 278.

FOSTER SDD (1985) Groundwater pollution protection in developing countries. In: Matthess G, Foster SS, Skinner AC (eds.) Theoretical Background, Hydrogeology and Practice of Groundwater Protection Zones. IAH International Contributions to Hydrogeology 6 167-200.
GEYH M (2000) Environmental Isotopes in the Hydrological Cycle, Volume 4: Groundwater. IHP-V, UNESCO, Paris. URL: http:// www.hydrology.nl/images/docs/ihp/Mook IV.pdf (Accessed 21 October 2011).

GIRARD P and HILLAIRE-MARCEL C (1997) Determining the source of nitrate pollution in the Niger discontinuous aquifers using the natural ${ }^{15} \mathrm{~N} /{ }^{14} \mathrm{~N}$ ratios. J. Hydrol. $199239-251$.

GNIP (GLOBAL NETWORK OF ISOTOPES IN PRECIPITATION) (2011) Rainfall data of Harare, Zimbabwe. URL: http://nds121.iaea. org/wiser/index.php (Accessed 10 May 2011).

HADAS A, SAGIV B and HARUVY N (1999) Agricultural practices, soil fertility management modes and resultant nitrogen leaching rates under semiarid conditions. Agric. Water Manage. 42 81-95.

HEATON THE and VOGEL JC (1981) Excess air in groundwater. J. Hydrol. 50 201-216.

HEATON THE, TALMA AS and VOGEL JC (1983) Origin and history of nitrate in confined groundwater in the Western Kalahari. J. Hydrol. $62243-262$

HEATON THE (1984) Sources of the nitrate in phreatic groundwater in the Western Kalahari. J. Hydrol. 67 249-259.

HEATON THE (1985) Isotopic and chemical aspects of nitrate in the groundwater of the Springbok Flats. Water SA 11199208.

HUYSER DJ (1982) The Chemical Quality of the Underground Waters of South-West Africa/Namibia (in Afrikaans). Vol 1-3. Department of Water Affairs, Pretoria/Windhoek.

JACKS G, SEFE F, CARLING M, HAMMAR M and LETSAMAO $P$ (1999) Tentative nitrogen budget for pit latrines in eastern Botswana. Environ. Geol. 38 199-203.

JACKS G and SHARMA VP (1983) Nitrogen circulation and nitrate in groundwater in an agricultural catchment in southern India. Environ. Geol. 5 (2) 61-64.

KAOWN D, KOH DC, MAYER B and LEE KK (2009) Identification of nitrate and sulfate sources in groundwater using dual stable isotope approaches for an agricultural area with different land use (Chuncheon, mid-eastern Korea). Agric. Ecosyst. Environ. 132 (3-4) 223-231.

KENDALL C (1998) Tracing nitrogen sources and cycles in catchments. In: Kendall C and McDonnell JJ (eds.) Isotope Tracers in Catchment Hydrology. Elsevier, Amsterdam. 519-576.

KIRCHNER J, TREDOUX G, WIERENGA A, CHRISTELIS G and WRABEL J (2002) Namibia: Assessment of the recharge to the Stampriet Artesian Basin to formulate a groundwater management plan for sustainable use of the resource in the southeast Kalahari in the Republic of Namibia. IAEA Project RAF 8/029, Technical Report. Department of Water Affairs, Windhoek, Namibia. 30 pp (excl. appendices).

LAFTHOUHI NE, VANCLOOSTER M, JALAL M, WITAM O, ABOUFIRASSI M, BAHIR M and PERSOONS E (2003) Groundwater nitrate pollution in the Essaouira Basin (Morroco). Comp. R-Géosci. 335 307-317.

LAWRENCE CR (1983) Nitrate-rich groundwaters of Australia. Technical Paper 79, Research Project 74/58. Department of Research and Energy, Australian Water Resources Council. 110 pp.

LITHERLAND M (1982) The geology of the area around Mamuno and Kalkfontein, Ghanzi District, Botswana. Distr. Mem. 4, Geol. Surv., Lobatse, Botswana. 145 pp.

LOWE M and WALLACE J (2001) Evaluation of potential geologic sources of nitrate contamination in ground water, Cedar Valley, Iron County, Utah, with emphasis on the Enoch area. Special Study 100. Utah Geological Survey. $50 \mathrm{pp}$.

LUBCZYNSKI MW (2000) Groundwater evapotranspiration Underestimated component of groundwater balance in a semiarid environment - Serowe case, Botswana. In: Silolo O (ed.). Groundwater: Past Achievements and Future Challenges. Balkema, Rotterdam. 199-204.

MARRETT DJ, KHATTAK RA, ELSEEWI AA and PAGE AL (1990) Elevated nitrate levels in soils of the eastern Mojawe desert. $J$. Environ. Qual. 19 658-663.

MODIE BN (1996) The geology of the Ghanzi Ridge. Distr. Mem. 7, Dept Geol. Surv., Lobatse, Botswana. 81 pp.

MOROSINI M (1996) Chemical-isotopic character, origin and 
evolution of groundwater in western Ghanzi District, Botswana. Dept. Geol. Surv., Lobatse, Botswana. 56 pp.

NETTERBERG F (1980) Geology of southern African calcretes: 1. Terminology, description, macrofeatures and classification. Trans. Geol. Soc. S. Afr. 83 255-283.

NOAA (NATIONAL OCEANIC AND ATMOSPHERIC ADMINISTRATION). Previous extreme events 2000. URL: http:// lwf.ncdc.noaa.gov/oa/climate/severeweather/rainfall.html\#previous (Accessed 11 November 2011).

OSENBRÜCK K, STADLER S, SÜLTENFUSS J, SUCKOW A and WEISE SM (2009) Impact of recharge variations on water quality as indicated by excess air in groundwater of the Kalahari, Botswana. Geochim. Cosmochim. Acta 73 911-922.

PACHECO J, MARIN L, CABRERA A, STEINICH B and ESCOLERO O (2001) Nitrate temporal and spatial patterns in 12 water supply wells, Yucatan, Mexico. Environ. Geol. 40 (6) 708-715.

RAZOWSKA-JAWOREK L, SADURSKI A (eds.) (2004) Nitrate in groundwaters. IAH Hydrogeology Sel. Pap. 5 247-258.

RINGROSE S, VANDERPOST C and MATHESON E (1998) Analysis of soil organic carbon and vegetation cover trends along the Botswana Kalahari transect. J. Arid Environ. 38 (3) 379-396.

ROSENTHAL E, MAGARITZ M, RONEN D and GILEAD D (1988) Groundwater contamination by nitrates and chlorides washed out from phosphorite ores in the Negev desert, Israel. J. Contam. Hydrol. 3 (1) 27-36.

ROSENTHAL E, MAGARITZ M, RONEN D and RODED D (1987) Origin of nitrates in the Negev Desert, Israel. Appl. Geochem. 2 (3) 347-354.

SAÂDI Z and MASLOUHI A (2003) Modeling nitrogen dynamics in unsaturated soils for evaluating nitrate contamination of the Mnasra groundwater. Adv. Environ. Res. 7 803-823.

SCHWIEDE M (2007) Erkundung der Prozesse der Nitratanreicherung in Aquiferen des südlichen Afrikas - Ermittlung von Ursache und Ausmaß der Nitratauswaschung aus Böden ins Grundwasser im Projektgebiet Serowe/Orapa. PhD thesis, Univ. Hannover, Germany.

SELAOLO ED (1998) Tracer studies and groundwater recharge assessment in the Eastern Fringe of the Botswana Kalahari. The Lethlakeng - Botlhapatlou Area. Ph.D. thesis, Free University of Amsterdam. 228 pp.

SGAB (Swedish Geological Survey) (1988) Serowe - Groundwater Resources Evaluation Project. Internal report. Dept. Geol. Surv., Lobatse, Botswana.

SHOMAR B, OSENBRÜCK K and YAHYA A (2008) Elevated nitrate levels in the groundwater of the Gaza Strip: Distribution and sources. Sci. Total Environ. 398 (1-3) 164-174.

SILVA SR, KENDALL C, WILKISON DH, ZIEGLER AC, CHANG CCY and AVANZINO RJ (2000) A new method for collection of nitrate from fresh water and the analysis of nitrogen and oxygen isotope ratios. J. Hydrol. 228 22-36.

STADLER S, OSENBRÜCK K, KNÖLLER K, SUCKOW A, SÜLTENFUSS J, OSTER H, HIMMELSBACH T and HÖTZL H (2008) Understanding the origin and fate of nitrate in groundwater of semi-arid environments. J. Arid Environ. 72 (10) 1830-1842.

STADLER S (2005) Investigation of natural processes leading to nitrate enrichment in aquifers of semi-arid regions. Ph.D. Thesis., Univ. Karlsruhe, Germany. Available as: Schriftenreihe angewandte Geologie Karlsruhe (2006) 71. 238 pp.

STADLER S, OSENBRÜCK K, SUCKOW A, HIMMELSBACH
T and HÖTZL H (2010a). Groundwater flow regime, recharge and regional-scale solute transport in the semi-arid Kalahari of Botswana derived from isotope hydrology and hydrochemistry. J. Hydrol. 388 291-303.

STADLER S, OSENBRÜCK K, DUIJNISVELD WHM, SCHWIEDE $\mathrm{M}$ and BÖTTCHER J (2010b) Linking chloride mass balance infiltration rates with chlorofluorocarbon and $\mathrm{SF}_{6}$ groundwater dating in semi-arid settings: potential and limitations. Isotopes Environ. Health Stud. 46 (3) 312-324.

TALMA AS, TREDOUX G and ENGELBRECHT JFP (2009) Behaviour of nitrogen in the unsaturated zone in southern Africa. In: Application of Isotopes to the Assessment of Pollutant Behaviour in the Unsaturated Zone for Groundwater Protection. TECDOC-1618, IAEA, Vienna.

TALMA AS and TREDOUX G (2005) Isotopic source identification of nitrate in the groundwater of semi-arid southern Africa. In: Vogel $\mathrm{H}$ and Chilume C (eds.). Environmental Geology in Semi-Arid Environments. Dept. Geol. Surv., Lobatse, 92-102.

THOMAS DSG and SHAW PA (1991) The Kalahari Environment. Cambridge University Press, Cambridge. 284 pp.

THOMAS DSG and SHAW PA (2002) Late Quaternary environmental change in central southern Africa: new data, synthesis, issues and prospects. Quat. Sci. Rev. 21 783-797.

TREDOUX G and TALMA AS (2006) Nitrate pollution of groundwater in southern Africa. In: Xu Y and Usher B (eds.) Groundwater Pollution in Africa, 15-36. Taylor and Francis, Leiden. 353 pp.

TREDOUX G, ENGELBRECHT JP and TALMA AS (2005) Nitrate in groundwater in arid and semi-arid parts of southern Africa. In: Vogel H and Chilume C (eds.). Environmental Geology in SemiArid Environments. Dept. Geol. Surv., Lobatse. 121-133.

TREDOUX G, ENGELBRECHT JP and TALMA AS (2001) Nitrate in groundwater in southern Africa. In: Seiler K-P and Wohnlich $\mathrm{S}$ (eds.). New Approaches Characterizing Groundwater Flow. Swets and Zeitlinger, Lisse, Netherlands. 663-666.

VERHAGEN BT, MAZOR E and SELLSCHOP JPF (1974) Radiocarbon and tritium evidence for direct recharge to groundwater in the northern Kalahari. Nature 249643644.

VERHAGEN BT (1995) Semiarid zone groundwater mineralization processes as revealed by environmental isotope studies. In: Adar E and Leibundgut C (eds.). Application of Tracers in Arid Zone Hydrology. IAHS Publ. 232 245-266.

WALVOORD MA, PHILIPS FM, STONESTROM DA, EVANS RD, HARTSOUGH PC, NEWMAN BD and STRIEGL RG (2003) A reservoir of nitrate beneath desert soils. Science 302 (7) 1021-1024.

WHO (WORLD HEALTH ORGANISATION) (1998) Guidelines for Drinking-Water Quality ( $2^{\text {nd }}$ edn.). Appendum to Vol. 2. Health criteria and other supporting information, 64-80, WHO, Geneva.

WILLIAMS AE, JOHNSON JA, LUND LJ and KABALA ZJ (1998) Spatial and temporal variations in nitrate contamination of a rural aquifer, California. J. Environ. Qual. 27 1147-1157.

WRABEL J (2005) Investigation of the processes leading to nitrate enrichment in the Kamtsas quartzite aquifer, Namibia. In: Vogel $\mathrm{H}$ and Chilume C (eds.) Environmental Geology in Semi-Arid Environments, 134-139. Dept. Geol. Surv., Lobatse, Botswana. 289 pp.

ZWIKULA T (2005) Evaluation of groundwater quality in Ramotswa, southeastern Botswana. In: Vogel H and Chilume C (eds.) Environmental Geology in Semi-Arid Environments, 24-28. Dept. Geol. Surv., Lobatse, Botswana. 289 pp. 